\title{
The Strategy of Welfare Improvement for Salt Farmers in Indonesia
}

\author{
Bambang Sudaryana ${ }^{1, *}$, Puji Pramesti ${ }^{1}$ \\ ${ }^{1}$ Politeknik LP3I Bandung West Java Indonesia
}

\begin{abstract}
Until now, production of salt in Indonesia is done by salt farmers and PT. Garam Indonesia as the only state company that produces salt. As the perpetrators of production which contribute greatly to the national salt production, salt farmer is considered not prosperous. In general, they depend on marine and coastal resources, use requires large investment and rely heavily on season. Climate and weather conditions that are often hostile, the price mechanism and the salt market tend to be contrast to the condition of farmers, this is what makes salt business is risky. The goals of this research are: 1. Improving the Welfare of salt farmers through a focused and effective empowerment. 2. Improving government'spolicies on salt. To conclude, Empowerment of salt farmers in Indonesia should be focused and effective, salt governance and policy revisions significantly affect the welfare of salt farmers.
\end{abstract}

\section{Introduction}

Indonesia is in the on-going process to Achieve food security, as mentioned in Act No.7 of 1996. It is supported by the very spacious potential of marine, with the facts that Indonesian coastline is very long, and, Indonesia is a country with Tropical climate. It is very likely that Indonesia becomes the country with largest salt producer in the world. Official Data states that the ratio of domestic salt production needs is not comparable with national results of salt. According to the calculation of demand, the need for salt in the country Reached $3,251,691$ tons, while the national salt production only $1,113,118$ tons. To meet the short comings of the required commodity, it is crucial to import about 2,6152 million tons. (Speech of the Minister of Maritime Affairs in the Congress of People's Salt, Bangkalan, Madura Indonesia July 2012). It's not unusual why this salt commodity can be interesting and important to be studied. Salt is one of the strategic commodities, that the country Includes it in to nine basic material needs of society. Salt is not only used for domestic consumption, but is also used for the needs of industry (pharmaceutical, mining, fertilizers and others). Problems in national salt production influences Several major issues, namely the production, infrastructure, institutional, marketing and supply demand. When we look at the history of Indonesia during the Dutch colonial period, salt is an important commodity and quite profitable, so it was monopolized private parties. (Handbook of the Netherlands Indies 1930:121).
The solution is to continue to maintain and improve their food prosperity through various government programs that support the achievement of national food security. The government policy to import salt has been controversial (Nurhayat, 2012; Sujatmiko, 2013; Firdaus, 2013; Rismana, 2013). The government policy to import salt, particularly the salt for industry is contrary to the logic of the potential length of the beach Indonesia which correlates with the ability of the national salt production. This shows the error of national government's salt policy, in the relation with the fact that Indonesia is still importing salt. Salt as agricultural commodities must be managed through a synergic policy, from infrastructure, social, economic, and education, so, that there is production continuity of salt to meet the needs of national demand. National salt category can be grouped into three general scopes, namely, the production, marketing, and, supply and demand. Problems of production refer to the difficulty of salt production that is very dependent on the climate. The technology used is still very reliant on weather factors. Indonesian that has relatively short drought climate is strongly related to the production of salt. Salt production is a line of labour intensive business that needs a deep consideration related to capacity of substantial power. Problem of location is significant to salt works that has varies of scales. The condition of existing manufacturers that is generally covered with weak-economic farmers, and, not to mention, the ownership structure of land by landowners, and sharecroppers with a distribution system that is not fair to the tiller; their limited working capital so that farmers are trapped in debt bondage system; and the low price of salt farmers causing some people in salt works land has

\footnotetext{
* Corresponding author: Bambangsudaryana58@gmail.com
} 
been converted and this led to the low production of salt (Latitude, 2013).

There are problems of supply and demand on the national salting, According Latitude(2013). It Consist of the supply, a certain moments, excess of supply or shortage of supply, seasonal production, monopolistic goods or no substitution. The offered salt in the form of detached and processed, it is same with the origin production of PT. Garam Indonesia and also Farmers. On the demand side, there are problems related to its sustainability, the increase of demand, in-elastic demand. It is especially for food consumption, the fishing industry, and food industry, the demand is quite jumbled. The last one, problem also covers the scattered and uneven request. Since the production is abundant, the power position of farmers is in weak position, so, price is fluctuated each year. Potential production of domestic salt has a different ability due to technical differences between the salt production of PT. Garam Indonesia and salt farmers. In rare circumstances that caused the decline of the salt supply in the country (due to climate), the government made policies to import salt. The import of salt is done to meet the needs of a salt shortage in the country but on the salt trade system which is apply no, it considered needs some improvement.

This certainly complex problems that can't be solved by only one party, and in a short time. It requires master plan from government as a regulator, as well as the executor who has power in politics and national economy. Synergy between government institutions themselves, for example the Ministry of Maritime Affairs and Fisheries, the Ministry of Industry, Ministry of Health, Ministry of Commerce, Ministry of Finance, Local Government and DRPD district centres of salt, and all parties associated with policy making and execution of the production chain, distribution, and national salt consumption is considered very important. This synergy will be a long-term solution for Indonesia's inability to meet the needs of national salt, both households and industry. It is proper for us as a nation to look far ahead in the settlement of the current problems in the field with one stop solution. So, the expected settlement does not patchy and only a mere momentary solution.

Conference on the Food and Agriculture in 1943 initiated the concept of a "secure, adequate and suitable supply of food for everyone". The definition of food security varies greatly, but generally refers to the definition of the World Bank (1986) and Maxwell and Frankenberger (1992), namely "access by all people at all times to the sufficient food for healthy living (secure access at all times to sufficient food for a healthy life). Food Agriculture Organization (FAO) states that the supply that dependent on food imports to the country of more than 100 millions, will make it difficult to advance the nation and independent. One of the serious problems faced by Indonesia is self-sufficiency, and food security. As a country endowed with fertile agricultural natural resource, our nation also faces the issue of resilience and self-sufficiency. Food politics is supposed to be in favour to the consumer, where the orientation is meeting the needs of consumers, especially for salt commodities, but it becomes pragmatic. Imports can actually be fatal, both in terms of import costs that need special allocations from the state budget, not to mention the risk the salt farmers that certainly would be jeopardized income. Today, the challenges of increasingly complex salt farming sector must be addressed not only about how the government's ability to increase production in order to maintain the resilience and food security, but more than that, also regarding how to improve the welfare of the actors in the agro-food sector, such as jobs and increase the income of farmers.

It should be recognized that the agricultural sector policies on salt is prioritizing the aspects of production to meet the needs of local consumers, while the welfare and needs of farmers it is still marginalized.

PT. Garam Indonesia is a State-owned Enterprise which has the vision of becoming the leading salt company in Southeast Asia and providing value added to the stakeholders. Salt production and marketing of raw materials and processed salt of PT. Garam Indonesia tends to fluctuate from year 2004-2011. And it is in accordance with that criticism by the Ministry of Maritime Affairs and Fisheries to produce salt.

Productivity of PT. Garam Indoensia is considered very low, but this state receiving State Capital Participation in billions of rupiah. PT. Garam Indonesia consumption of salt production in 2012 is far from complete, it is only capable to produce 340,000 tons. Yet, the first report to the Ministry of Industry reaches 385,000 tons.

Displays the translation for the Conference of the Food and Agriculture in 1943 which initiated the concept of a "secure, adequate and suitable supply of food for everyone". The definition of food security varies greatly, but generally refers to the definition of the World Bank (1986) and Maxwell and Frankenberger (1992), namely "access by all people at all times to the sufficiency of food for healthy living (secure access at all times to sufficient food for a healthy life). "According to the food Agriculture Organization (FAO), supply dependence on food imports to the country is more than 100 million. It will make it difficult to advance the nation and independent. One of the serious problems faced by Indonesia is self-sufficiency and food security. As a country endowed with fertile agricultural natural resource, our nation also faced the issue of resilience and self-sufficiency. Food politics should be in favour of the consumer, where the orientation is meeting the needs of consumers for salt commodities salt. It is now still pragmatic. Imports can actually be fatal, both in terms of import costs that need special allocations from the state budget, not to mention the risk the salt farmers that certainly would be jeopardized income. Today, the challenges of increasingly complex salt farming sector must be addressed not only about how the government's ability to increase production in order to maintain the resilience and food security, but more than that, also regarding how to improve the welfare of the actors in the agro-food sector, such as jobs and increase the income of farmers.

During this time, the domestic market requires two types of salt, the salt that is destined for consumption and industry. Salt Consumption with $\mathrm{Na} \mathrm{Cl}$ of 94.7 
percent is used not only for consumption but also for salting and human consumption of food and livestock. Meanwhile, Industrial salt with $\mathrm{Na} \mathrm{Cl}$ content of 97 percent or higher levels of salt consumption is widely used for the leather industry, pharmaceuticals and textiles. The need for salt industry must import 100 percent or it reaches 3.3 million tons. While the national salt production $1,113,118$ tons that only meet the shortfall, and the rest of it must be imported.

Total salt imported during January 2014 reached 278 thousand tons, up $78 \%$ in volume. While the value of imports Reached US \$ 13.4 million, up to $75 \%$ in value of imports. In the same period years ago, in January 2013 , the import of salt recorded only $\$ 156$ thousand tons with the import value of US $\$ 7.7$ million. Based on supply-needs calculation, the total demand for salt Indonesia is 3 to 3,2 million. That isused for consumption, fish preservation, and so forth about 1.2 to 1.4 million tons and 1.8 million tons of industrial salt. In 2004 and 2012, the volume of imports is Increased annually.

Here are the data of imported salt to Indonesia:

a) Australia, which is the biggest salt supplier for Indonesia. In June 2013, the import of salt by Indonesia from Australia Reached 111 thousand tons or US \$ 5.4 million. Meanwhile, the previous month (May 2013) the entry of imported salt from Australia amounted to 98 thousand tons or US \$ 4.8 million. The cumulative (January to June 2013), the import of salt from Australia recorded 733 thousand tons or US \$ 34.2 million.

b) India, in June 2013, India did not supply salt to Indonesia. However, for the month of May 2013, the salt import from India reached 47 thousand tons, worth US \$ 1.97 million. If accumulated over 6 months in 2013, total imports of salt of India is 189 thousand tons or US \$ 7.89 million.

c) Germany, the import volume in June 2013 was 34 tons or US \$ 119 thousand. Previous months, imports salt from Germany is not too much different. Within six months, salt imports from Germany Reached 177 tons or \$ 445 thousand.

d) New Zealand, salt imports from New Zealand in June 2013 Reached 48 tons or US \$ 19 thousand. While in May 2013, salt imports from New Zealand Reached 480 tons or US \$ 194 thousand.
While in the period January to June 2013, total salt imports from New Zealand Reached 816 tons or US \$ 325 thousand. e) Singapore, the amount of salt imported from Singapore in June 2013 Reached $293 \mathrm{~kg}$ or US \$ 1.012. During January to June 2013, the salt imported from Singapore entered at 7.2 tons or US \$ 57 thousand. In addition there is a collection of other countries with total imports of salt during the month of June amounted to 25.3 tons, or US \$ 4.370 and for a period of 6 months in 2013 amounted to 663.9 tons or US \$ 142 thousand

Those data and facts show that Indonesia in fulfilling the needs of domestic salt by importing salt from other countries. Midgley (1995) describe three important strategies in improving the welfare of the community, namely through an individual approach (individualist or enterprise approach), through a community approach (Communitarian approach), or by the role of the state (statist approach). And when it is viewed from the side of an individual approach, the welfare of the whole society will be achieved when each individual can improve their welfare. The efforts undertaken by this approach is to promote a culture of entrepreneurship, encourage the emergence of small businesses, and to encourage the participation of individuals in order to optimally utilize entrepreneurial culture and business climate. As described earlier, the condition of the salt farmers in the village is very alarming. Hence, their capacity building (empowerment) is important to up grad, looking at their contribution to the fulfilment of the national salt. Observing aspects of income derived from the salt farmers struggle during this time, it does not provide a significant contribution to economic growth. Economic growth tends to be slow, erratic and difficult to read. Delays of economic growth automatically interact with the process of economic equality.

In general, the farmers are in poverty, where they are mostly located in rural areas. To reduce poverty, it is good to outwit the farmers since it is very helpful in the process of independence and establish their identity. Their identity and existence of this form of independence became the driving side. When the policy was first adopted, importing is salt based on the consideration to meet domestic salt need that can not be met by the producers of industrial salt and salt consumption. That rule seems to consider the possibility of the impact of the legality of imported salt. In the preamble of the regulation stated "that in order to meet domestic demand for salt as a raw material in industries, as well as, increase the income and welfare of salt farmers, it is need to regulate the import of salt provisions". So, the government itself seems to also face a dilemma related to the trade of salt: on the one hand requires the supply, but on the other hand could certainly be a boomerang for the existence of salt people. Associated with government policy on import of salt, many people doubt whether the 
policy of import of salt, especially salt intake really is based on accurate data or research results.

The willingness of governments as reflected in its policies through the relevant ministry can not automatically be implemented in line with expectations. However, both the rules on paper and in practice turn out that the government lacks the ability to control the conditions in the field. Prices of salt on the market in reality only determined and controlled by a particular company, created a cartel in the salt trade system. Therefore, even though the government has tried to protect the people of salt at the time of harvest, in fact imported salt is still flooding which caused the price of salt people is very low. In fact, based on the findings in the field, farmers are generally not aware of any protection from the government, because there is no significant market uptake activity and still outstanding import salt.

\section{Material and Methodology}

\subsection{Research Location}

The research location is determined intentionally (purposive) in Cirebon. The choice of location is based on the consideration that the salting Cirebon District could represent the people/ farmers.

\section{Population and Sample}

The population in this study are share croppers salt. Method of sampling is done proportional random sampling. Number of samples /respondents are about 50 people. This amount is deemed to have met the numbers as expressed by Singarimbun and Effendi(1995) that samples with greater than 30 are included in a large sample.

\subsection{Method of collecting data}

The data used in this research are quantitative data and qualitative data that are obtained from both primary and secondary sources. The primary data are obtained by observation, questionnaires, and interviews. While secondary data are obtained from the village offices, district offices, the Department of Marine, Fisheries and Livestock, PT. Garam Indonesia and other related institutions.

This study uses survey, by interviewing the respondents using questionnaire. Sampling method in this research is done by using purposive sampling, the sampling technique with certain consideration. The method can be used if the sources correspondents interviewed are experts or working in a field, for example research on food, then the data source or resource person is the person who is addition (Sugiyono 2010). Purposive sampling method or judgment, in which the determination of sample obtained from consideration of the interviewer, with a note that the respondents who were interviewed are people who are experts or working in the field of research that is being studied or the late respondent meets the criteria specified by the interviewer (Fauzi2001).

$$
\mathrm{n}=\frac{\mathrm{N}}{\mathrm{N}(\mathrm{d} 2)+1}
$$

The data used in this research is primary data and secondary data. According to the governor (2011) in Yuliriane (2012), the primary data is data obtained directly from study subjects using a measuring device or appliance makers as a source of information of data, such as interviews, questionnaires, or observation. Secondary data were obtained with a literature study of the relevant agencies. Primary data were obtained from the respondent, while secondary data are obtained from relevant agencies such as the Central Bureau of Statistics(BPS), the Local Government Office of Cirebon District, and the books that are relevant to the research.

\subsection{Statistical Analysis}

Data obtained from the results of the study were analyzed using quantitative descriptive method. Descriptive method aimed to tell and interpret data with respect to the situation in a systematic, factual and accurate information on the facts and the relationship between variables to get the truth. Whereas quantitative methods aimed at raising the facts, state variables, and the phenomenon that occurs when current and present their study (Sugiono 2003). However, the criteria that should be analyzed in this study are described in the next section. The instrument is analyzed by using Pearson Product formula Moment Correlation(Pearson Product Moment Correlation), as follows:

$$
r_{x y}=\frac{N \sum x y-\left(\sum x\right)\left(\sum y\right)}{\left.\sqrt{\left\{N \sum x^{2}-\left(\sum x\right)^{2}\right\}\left\{N \sum y^{2}\right.}-\left(\sum y\right)^{2}\right\}}
$$

Structural equation model to be tested take the form of $\mathrm{Y}$ $=\rho x_{1} X_{1}+\rho x_{2} X_{2}+\rho y \varepsilon$. And The Multiple Linear Regression Analysis as follows: $\mathrm{Y}=\mathrm{a}+\mathrm{b}_{1} \mathrm{X}_{1}+\mathrm{b}_{2} \mathrm{X}_{2}+\varepsilon$.

\section{Result and Discussions}

1. Correlation between The Strategy of Salt Production Governance(X1), the implementation of policy (X2), with Welfare improvement of the Salt Farmer (Y)

By usingSPSS17, it is known that the multiple coefficient correlation between variables The Strategy (X1), the implementation of Policy $\left(\mathrm{X}_{2}\right)$, with welfare 
Improvement of the Salt Farmer (Y) are shown in the table as follow

\begin{tabular}{|c|c|c|c|c|c|}
\hline & & & Strategy & Policy & Welfare \\
\hline \multirow[t]{3}{*}{$\begin{array}{l}\text { Spear } \\
\text { man's } \\
\text { rho }\end{array}$} & Strategy & $\begin{array}{l}\text { Correlation Coefficient } \\
\text { Sig. (2-tailed) } \\
\text { N }\end{array}$ & $\begin{array}{c}1.000 \\
\cdot \\
55\end{array}$ & $\begin{array}{c}.732^{2 *} \\
.000 \\
55\end{array}$ & $\begin{array}{c}.821^{* *} \\
.000 \\
55\end{array}$ \\
\hline & Policy & $\begin{array}{l}\text { Correlation Coefficient } \\
\text { Sig. (2-tailed) } \\
\mathrm{N}\end{array}$ & $\begin{array}{l}.732^{* *} \\
.000 \\
55\end{array}$ & $\begin{array}{c}1.000 \\
\cdot \\
55\end{array}$ & $\begin{array}{l}.771^{* *} \\
.000 \\
55\end{array}$ \\
\hline & Welfare & $\begin{array}{l}\text { Correlation Coefficient } \\
\text { Sig. (2-tailed) } \\
\mathrm{N}\end{array}$ & $\begin{array}{c}.821^{* *} \\
.000 \\
55\end{array}$ & $\begin{array}{c}.771^{* *} \\
.000 \\
55\end{array}$ & $\begin{array}{c}1.000 \\
\cdot \\
55\end{array}$ \\
\hline
\end{tabular}

**. Correlation is significant at the 0.01 level (2-tailed).

Based on Table 1 the results of correlation Kendall's tau b is stated that variable The Strategy of Salt Production Governance $\left(\mathrm{X}_{1}\right)$ has a very close relationship with the variable Welfare improvement of the Salt Farmer (Y) of 0.938 , or by $93.80 \%$ and variable The Implementation of Policy $\left(\mathrm{X}_{2}\right)$ also has close links with the variable of Welfare Improvement of the Salt Farmer $(\mathrm{Y})$ of 0.874 or $87.40 \%$ and the Strategy $\left(\mathrm{X}_{1}\right)$ has a close relationship with the variable The Implementation of Policy $\left(\mathrm{X}_{2}\right)$ of 0.817 or $81.70 \%$

Multiple correlation coefficient of 0.989 means that the relationship between The Strategy of Salt Production Governance $\left(\mathrm{X}_{1}\right)$, The Implementation of Policy $\left(\mathrm{X}_{2}\right)$, and Welfare Improvement of the Salt Farmer(Y) is very close. Value $\mathrm{R}^{2}=0,989$ means that changes to Improve the Welfare of the Poor by $98.90 \%$ due to changes in the Strategy of Salt Production Governance $\left(\mathrm{X}_{1}\right)$ and The Implementation of Policy $\left(\mathrm{X}_{2}\right)$.

2. The Strategy of Salt Production Governance $\left(\mathbf{X}_{1}\right)$ significantly influences on Welfare Improvement of the Salt Farmer (Y)

Based on the correlation data that prove the influence of variables The Strategy of Salt Production Governance $\left(\mathrm{X}_{1}\right)$ to Improve the Welfare of the Salt Farmer (Y) that is calculated with a correlation coefficient of 0,989 or $\left(\mathrm{rx}_{1} \mathrm{y}\right)=0,989$ suggests the effect is very close, when compared with the coefficient as follows:

1. $0,00-0,20$ the relationship is very small and can be ignored

2. $0,20-0,40 \quad$ small relationship (not tight)

3. $0,40-0,70$ the relationship is moderate (close enough)
4. $\quad 0,70-0,90$
tight relationship
5. $0,90-1,00$
a very close relationship

Meanwhile, to declare the size of the contribution of variable $\mathrm{X}_{1}$ to $\mathrm{Y}$ variable or determinant coefficient is stated as $=r^{2} \mathrm{X} 100 \%$ or $(0,766)^{2} \times 100 \%=58,68 \%$, while the remaining $41.32 \%$ is determined by other variables. Then to find significant levels of correlation coefficients $\mathrm{X}_{1}$ on $\mathrm{Y}$ with one sided methods (one tailed) of output. Measured probability is yields 0.00 figure. Because the probability is much below 0.05 , then, the influence of The Strategy of Salt Production Governance to Improve the Welfare of the Salt Farmer is significant.

Table. 2. Summary Model ${ }^{\text {b }}$

\begin{tabular}{|c|c|c|c|c|c|}
\hline $\begin{array}{c}\text { Mode } \\
\mathrm{l}\end{array}$ & $\mathrm{R}$ & $\begin{array}{c}\mathrm{R} \\
\text { Square }\end{array}$ & $\begin{array}{c}\text { Adjuste } \\
\mathrm{d} \mathrm{R} \\
\text { Square }\end{array}$ & $\begin{array}{c}\text { Std. Error of } \\
\text { the } \\
\text { Estimation }\end{array}$ & $\begin{array}{c}\text { Durbin- } \\
\text { Watson }\end{array}$ \\
\hline 1 & $\begin{array}{c}.766 \\
\mathrm{a}\end{array}$ & .806 & .917 & 1.54556 & .532 \\
\hline
\end{tabular}

a.Predictor (Constant), strategy, policy

b. Dependent Variable: Welfare

Table 3. Coefficients ${ }^{\mathrm{a}}$

\begin{tabular}{|l|c|c|c|c|c|c|c|}
\hline & $\begin{array}{c}\text { Unstandard } \\
\text { ized } \\
\text { Coefficient } \\
\mathrm{s}\end{array}$ & $\begin{array}{c}\text { Standardi } \\
\text { zed } \\
\text { Coefficie } \\
\text { nts }\end{array}$ & & & & \multicolumn{2}{|c|}{$\begin{array}{c}\text { Collinearity } \\
\text { Statistics }\end{array}$} \\
\cline { 3 - 7 } Model & $\mathrm{B}$ & $\begin{array}{c}\text { Std. } \\
\text { Error }\end{array}$ & Beta & $\mathrm{T}$ & Sig. & $\begin{array}{c}\text { Toleran } \\
\text { ce }\end{array}$ & VIF \\
\hline $\begin{array}{l}\text { 1 Consta } \\
\text { nt) }\end{array}$ & 135 & 1.496 & & .509 & .707 & & \\
$\begin{array}{l}\text { Strateg } \\
\text { y }\end{array}$ & .611 & .319 & .733 & 13.3 & .000 & .412 & 2.430 \\
Policy & .427 & .323 & .723 & 9.28 & .000 & .412 & 2.430 \\
\hline
\end{tabular}

a. Dependent Variable: Welfare

The coefficient table illustrates that simple regression equation is as follows:

$\dot{Y}=a+b_{2} X_{2}=13,52+0,723 X_{2}$

Is:

$\mathrm{X}_{2}=$ The Implementation of Policy

$\mathrm{Y}=$ Improving the Welfare of the Salt Farmer

Constants of 13,52 states that there is no increase in the value of the variable The Implementation of Policy $\left(\mathrm{X}_{2}\right)$, then the value of Welfare improvement of the Salt Farmer (Y) is 13,52. The regression coefficient of 0,723 states that any additions (for the sign+) of the scores or grades Quality of care would rise to a score of 0,723

$\mathrm{T}$ test is used to test the significance of constant and variable Y (Improving the Welfare of the Salt Farmer). Coefficient tests the following variables:

Ha: The Implementation of Policy is significantly affect Welfare Improvement of the Salt Farmer 
Ho: The Implementation of Policy does not significantly affect Improving the Welfare of the Salt Farmer

The hypothesis in statistical form:

$\mathrm{Ha}: \operatorname{rx}_{2} \mathrm{y} \neq 0$

Ho : $\mathrm{rx}_{2} \mathrm{y}=0$

Basis for decision making: by comparing the value of $t$ arithmetic with $\mathrm{t}$ table as follows: If thet count $>t$ table, then $\mathrm{Ho}$ is rejected it means a significant regression coefficient

If the value oft $<\mathrm{t}$ table, then Ho accepted means of regression coefficients were not significant Value $=7.230$ (taken at coefficient value for the variable $\left(\mathrm{X}_{2}\right)$

$*$ The level of $\operatorname{significance}(\alpha)=0.05$

$* \mathrm{df}$ (degrees of freedom) amount $\mathrm{n}-2=55-2=53$

*Test done one side, so that the value $t$ table $=1.671$

Decision:

Because the value of $t$ count $>t$ table, or7,230 $>1.671$, then Ho is rejected seen in the column sig (significant) coefficient sig 0.000 or less than the probability value 0.05 or 0.05 value $>0,000$, then Ho is rejected and $\mathrm{Ha}$ is accepted, meaning that the regression coefficient is significant. Thus The Implementation of Policy significantly affects Welfare Improvement of the Salt Farmer. Thus the regression equation is:

$\dot{Y}=a+b_{1} x_{1}+b_{2} x_{2}=13,52+0,766 X_{1}+0,723 X_{2}$

is :

$\mathrm{X}_{1}=$ The Strategy of Salt Production Governance

$\mathrm{X}_{2}=$ The Implementation of Policy

$\mathrm{Y}=$ Improving the Welfare of the Salt Farmer

Constants of 16.44 states that if there is no increase in the value of the variable The Strategy of Salt Production Governance $\left(\mathrm{X}_{1}\right)$ and The Implementation of Policy $\left(\mathrm{X}_{2}\right)$, then the value of Welfare Improvement of the Salt Farmer (Y )is13,52. The regression coefficient of 0,766 and 0,723 states that any additions(for the sign+) of the scores or grades The Strategy and The Implementation of Policy will give rise to a score of 0,766 and 0,723

3. The Strategy of Salt Production Governance $\left(\mathrm{X}_{1}\right)$ and The Implementation of Policy $\left(\mathrm{X}_{2}\right)$ together equally influence significantly on Welfare Improvement of the Salt Former (Y)

F test in the ANOVA table is to test the significance of the constants and the dependent variable(Improving the Welfare of the Salt Farmer). Criteria regression coefficient test of The Strategy of Salt Production Governance and The Implementation of Policy to Improve the Welfare of the Salt Farmer is as follows:

Hypothesis to three proposals are

Ha : The Strategy of Salt Production Governance $\left(\mathrm{X}_{1}\right)$ and The Implementation of Policy $\left(\mathrm{X}_{2}\right)$ together -equally influence significantly on Welfare Improvement of the Salt Farmer (Y)

Ho : The Strategy of Salt Production Governance $\left(\mathrm{X}_{1}\right)$ and The Implementation of Policy $\left(\mathrm{X}_{2}\right)$ together -equally influence significantly on Welfare Improvement of the Salt Farmer (Y)

The hypothesis instatistical form:

$\mathrm{Ha}: \mathrm{r} \mathrm{x}_{1} \mathrm{x}_{2} \mathrm{y} \neq 0$

Ho : $r \mathrm{x}_{1} \mathrm{x}_{2} \mathrm{y}=0$

Table 4. ANOVA ${ }^{\mathrm{b}}$

\begin{tabular}{|l|c|c|c|c|c|}
\hline \multicolumn{1}{|c|}{ Model } & $\begin{array}{c}\text { Sum of } \\
\text { Squares }\end{array}$ & df & $\begin{array}{c}\text { Mean } \\
\text { Square }\end{array}$ & F & Sig. \\
\hline $\begin{array}{l}\text { 1 Regress } \\
\text { ion }\end{array}$ & 6979.349 & 2 & 3489.675 & $\begin{array}{c}1023.4 \\
33\end{array}$ & $.000^{\mathrm{a}}$ \\
$\begin{array}{l}\text { Residua } \\
1\end{array}$ & 156.936 & 55 & 2.092 & & \\
Total & 7136.286 & 53 & & & \\
\hline
\end{tabular}

a. Predictors: (Constant), Strategy, Policy

b. Dependent Variable: Welfare

Taken from the table anova ${ }^{\mathrm{b}} \mathrm{F}$ count $=10,23$ Basic decision-making: by comparing the value of $\mathrm{F}$ arithmetic with $\mathrm{F}$ table value is as follows:

If $F$ count $>F$ table, then Ho is rejected. It means, this is significant regression coefficient.

If the value of $\mathrm{F}$ arithmetic $<\mathrm{F}$ table, then Ho is accepted. It means, the regression coefficients were not significant. Finding the value of $F$ calculated using the $F$ table with the formula:

Significance level $(\alpha)=0.05$ significance level $(\alpha)=0,05$

$\mathrm{F}_{\text {table }}=\mathrm{F}(1-\alpha)(\mathrm{dk}=\mathrm{k}),(\mathrm{dk}=\mathrm{n}-\mathrm{k}-1)$

$=F(1-\alpha)(\mathrm{dk}=3),(\mathrm{dk}=55-2-1)$

$=\mathrm{F}(1-0,05)(3,52)$

How to find $\mathrm{F}$ table $=3$, as the numerator and the denominator 52

F table $=4.08$ (interpolation)

Decision :

It turned out that $\mathrm{F}$ count $>\mathrm{F}$ table, or $10,23>4.08$ then Ho is rejected and $\mathrm{Ha}$ is accepted. It means that The Strategy of Salt Production Governance $\left(\mathrm{X}_{1}\right)$ and The Implementation of Policy (x2) together-equally influence significantly on Welfare Improvement of the Salt Farmer(Y). It appears that at column Sig(significant) in the table Anova ${ }^{b}$ the Sig. 0,000or smaller than the probability value 0.05 or 0.05 value $>0.000$, then Ho is rejected and $\mathrm{Ha}$ accepted, meaning that multiple regression coefficient is significant. So, The Strategy of 
Salt Production Governance $\left(\mathrm{X}_{1}\right)$ and The Implementation of Policy $\left(\mathrm{X}_{2}\right)$ together -equally influence significantly on Improving the Welfare of the Salt Farmer (Y)

\section{Conclusion and Discussion}

Research findings indicate various conclusions, related to:

1. The relationship / correlation is very strong / strong between The Strategy of Salt Production Governance $\left(\mathrm{X}_{1}\right)$ and The Implementation of Policy $\left(\mathrm{X}_{2}\right)$ together with variable Improving the Welfare of the Salt Farmer (Y) of 0.766 or $76,60 \%$ and the remaining $23.40 \%$ are other factors that are not included in the research model (Epsilon).

2. There is significant influence of variables The Strategy of Salt Production Governance $\left(\mathrm{X}_{1}\right)$ to Improving the Welfare of the Salt Farmer (Y)

3. There is significant influence of variables The Implementation of Policy $\left(\mathrm{X}_{2}\right)$ on Improving the Welfare of the Salt Farmer (Y)

4. There is significant influence of variables The Strategy of Salt Production Governance $\left(\mathrm{X}_{1}\right)$ and The Implementation of Policy $\left(\mathrm{X}_{2}\right)$ together toward Improving the Welfare of the Salt Farmer (Y).

\section{Acknowledgment}

We are gratefully acknowledged to Local Government of Cirebon, West Java. Special thanks to the Regent of the respective Public Administration Institution, Local Government of Cirebon and all subjects who participated in the study are gratefully acknowledged.

Conflict of interest declaration: There is no conflict of interest among the authors.

Funding: This study received no specific grant from any funding agency.

Authors' contributions Bambang Sudaryana, conception of study, data collection, analysis and interpretation of results, drafting of manuscript, review of manuscript and interpretation of results.

\section{References}

1. Adiprayoga, Gatot. "Penanggulangan Kemiskinan Melalui Pemberdayaan Masyarakat," dalam Jurnal ASPIRASI, Vol. XVIII No. 1, Jember: Fakultas Ilmu Sosial dan Ilmu Politik Universitas Jember, Juli 2008

2. Dillon, HS. "Kemiskinan di Negara Berkembang: Masalah Konseptual dalam Global", dalam Jurnal Prisma No. 3/XIII/1993. Jakarta: LP3ES, 1993
3. Elliot, T. Charles. Perfect Empowerment, New York: Unesco. http://www.Dinas Kelautan dan Perikanan Kabupaten Lombok Barat, 1987

4. Iskandar Dinata, Pemberdayaan petani garam dalam mewujudkan kesejahteraan sosial (potret petani garam di desa pandai kecamatan woha kabupaten bima). Volume 9, Nomor2, Juli-Desember 2013

5. Nasirin, Chairun.. "Alternatif Model Kebijakan dalam Upaya Penanggulangan Kemiskinan di Indonesia", dalamASPIRASI Vol. XVIII, No. 1 Juli 2008, Fakultas Ilmu Sosial dan Ilmu Politik Universitas Jember, 2008 